\title{
A new acidophilic thermostable endo-1,4- $\beta$ - mannanase from Penicillium oxalicum GZ-2: cloning, characterization and functional expression in Pichia pastoris
}

Hanpeng Liao, Shuixian Li, Haiping Zheng, Zhong Wei, Dongyang Liu, Waseem Raza, Qirong Shen and Yangchun $\mathrm{Xu}^{*}$

\begin{abstract}
Background: Endo-1,4- $\beta$-mannanase is an enzyme that can catalyze the random hydrolysis of $\beta-1,4$-mannosidic linkages in the main chain of mannans, glucomannans and galactomannans and has a number of applications in different biotechnology industries. Penicillium oxalicum is a powerful hemicellulase-producing fungus (Bioresour Technol 123:117-124, 2012); however, few previous studies have focused on the cloning and expression of the endo-1,4- $\beta$-mannanase gene from Penicillium oxalicum.

Results: A gene encoding an acidophilic thermostable endo-1,4- $\beta$-mannanase (E.C. 3.2.1.78) from Penicillium oxalicum GZ-2, which belongs to glycoside hydrolase family 5, was cloned and successfully expressed in Pichia pastoris GS115. A

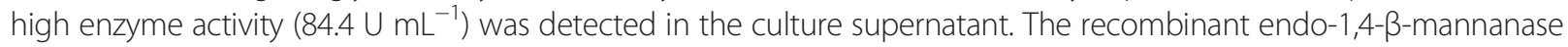
(rPoMan5A) was tagged with $6 \times$ His at its C-terminus and purified using a Ni-NTA Sepharose column to apparent homogeneity. The purified rPoMan5A showed a single band on SDS-PAGE with a molecular mass of approximately

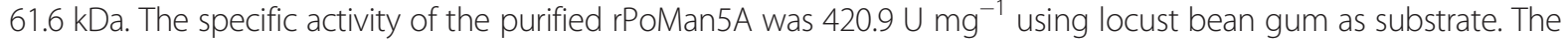
optimal catalytic temperature (10 min assay) and $\mathrm{pH}$ value for rPoMan5 A are $80^{\circ} \mathrm{C}$ and $\mathrm{pH} 4.0$, respectively. The rPoMan5A is highly thermostable with a half-life of approximately $58 \mathrm{~h}$ at $60^{\circ} \mathrm{C}$ at pH 4.0 . The $K_{m}$ and $V_{\text {max }}$ values for locust bean gum, konjac mannan, and guar gum are $7.6 \mathrm{mg} \mathrm{mL}^{-1}$ and $1425.5 \mu \mathrm{mol} \mathrm{min}{ }^{-1} \mathrm{mg}^{-1}, 2.1 \mathrm{mg} \mathrm{mL}^{-1}$ and

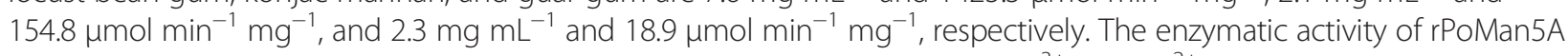
was not significantly affected by an array of metal ions, but was inhibited by $\mathrm{Fe}^{3+}$ and $\mathrm{Hg}^{2+}$. Analytical results of hydrolytic products showed that rPoMan5A could hydrolyze various types of mannan polymers and released various mannose and manno-oligosaccharides, with the main products being mannobiose, mannotriose, and mannopentaose.

Conclusion: Our study demonstrated that the high-efficient expression and secretion of acid stable and thermostable recombinant endo-1, 4- $\beta$-mannanase in Pichia pastoris is suitable for various biotechnology applications.
\end{abstract}

Keywords: Endo-1,4- $\beta$-mannanase, Gene cloning, Expression system, Pichia pastoris, Penicillium oxalicum

\footnotetext{
* Correspondence: ycxu@njau.edu.cn

Jiangsu Collaborative Innovation Center for Solid Organic Waste Utilization,

College of Resources and Environmental Science, Nanjing Agricultural

University, Nanjing 210095, China
}

\section{Biomed Central}

(c) 2014 Liao et al.; licensee BioMed Central Ltd. This is an Open Access article distributed under the terms of the Creative Commons Attribution License (http://creativecommons.org/licenses/by/4.0), which permits unrestricted use, distribution, and reproduction in any medium, provided the original work is properly credited. The Creative Commons Public Domain Dedication waiver (http://creativecommons.org/publicdomain/zero/1.0/) applies to the data made available in this article, unless otherwise stated. 


\section{Background}

Mannan polysaccharides are the major components of softwood hemicellulose and can be classified into linear mannan, glucomannan, galactomannan, and galactoglucomannan [1]. They consist of a backbone of $\beta$-1,4-linked mannose, which may be interrupted by $D$-glucose in glucomannans. Due to the complex nature of these polysaccharides, a combination of different enzymes such as endo-1,4- $\beta$-mannanase (EC 3.2.1.78), $\beta$-mannosidase (EC 3.2.1.25), $\beta$-glucosidase (EC 3.2.1.21), $\alpha$-galactosidase (EC 3.2.1.22) and acetyl mannan esterase (EC 3.1.1.6) are required to complete the hydrolysis of heteromannans. Among them, the most important is endo-1,4- $\beta$-mannanase (EC 3.2.1.78), which can catalyze random internal hydrolysis of $\beta-1,4-$ mannosidic linkages in the main structure of $\beta-1,4$-mannans, glucomannans and galactomannans by releasing small manno-oligosaccharides [2]. This type of enzyme has shown a wide range of potential uses in industrial applications, including food/feed, pharmaceutical, pulp/paper, gas well stimulation [3], as well as for second generation biofuels $[4,5]$. Mannans, the major components of hemicellulose, associate with lignin and cellulose in lignocellulosic biomass, physically hindering cellulase access to the fibers and reducing the efficiency of enzymatic hydrolysis [6]. In the bioenergy process, the breakdown of lignocellulose to fermentable sugars by enzymatic hydrolysis is one of the decisive bottlenecks, due to the recalcitrance of the plant cell wall and the high cost of enzymes. Based on this application, these enzymes have recently received much attention for industrial use, with an everincreasing demand for renewable bioenergy utilization.

During the past few decades, many endo-1,4- $\beta$ mannanases have been purified and characterized from plants, bacteria, fungi and metazoans, among which the filamentous fungi are considered to be good candidates for the industrial production of endo-1,4- $\beta$-mannanases [7]. Many studies have been performed focusing on discovering new endo-1,4- $\beta$-mannanases with robust enzymatic activity by various methods, such as mutating enzyme-producing strains and optimizing fermentation conditions, and on producing endo-1,4- $\beta$-mannanases by fermentation on an industrial scale $[8,9]$. However, a suitable endo-1,4- $\beta$-mannanase for industrial use involves not only a high enzymatic hydrolysis activity; but thermo- and acidic-stability are also needed as many industrial bioprocesses require the use of enzymes at low $\mathrm{pH}$ and high temperature conditions to prevent contamination by other microbes [10-12].

P. oxalicum GZ-2, an agricultural biomass-degrading filamentous fungus, was isolated in our lab from decaying-wood acidic soil and showed favorable acidophilic hemicellulase-producing ability [13]. When P. oxalicum GZ-2 was incubated with agricultural waste (corn cob) as carbon source, an obvious mannanase activity could be determined in the culture supernatant (data not shown). In this study, a new acidic thermostable GH5 endo-1,4- $\beta$-mannanase gene (poman5A) from $P$. oxalicum GZ-2 was cloned and heterologously expressed in Pichia pastoris GS115. To our knowledge, this is the first example of cloning and expression of an acidic thermostable endo-1,4- $\beta$-mannanase gene from $P$. oxalicum. The biochemical characteristics of the recombinant enzyme were also evaluated. The superior biochemical and hydrolytic properties of rPoMan5A make it a highly useful candidate for various industrial applications.

\section{Results}

Cloning and sequence analysis of the endo-1,4- $\beta$-mannanase gene from $P$. oxalicum GZ-2

A 772-bp gene fragment was amplified from the gDNA of strain GZ-2 using the degenerate primers manA-df and manA-dr. Sequence analysis indicated that the fragment showed $76 \%$ identity with an endo-1,4- $\beta$-mannanase from Aspergillus aculeatus (GenBank: L35487.1). To amplify the full-length endo-1,4- $\beta$-mannanase gene the 5' and 3' flanking regions were obtained using self-formed adaptor PCR (SEFA-PCR). All fragments were assembled with core regions to create a $1671 \mathrm{bp}$ sequence containing a complete chromosomal gene of 1380 bp predicted by FGENESH (http://linux1.softberry.com/berry.phtml). The full-length cDNA sequence of endo-1,4- $\beta$-mannanase (PoMan5A) was contained in an open reading frame of $1380 \mathrm{bp}$, which was cloned from the synthesized cDNA using the manA-f and manA-r primers. Three introns interrupted the PoMan5A coding sequence according to the alignment of the DNA and cDNA sequences. A putative 33-residue signal peptide at the $\mathrm{N}$-terminus was predicted by the SignalP server system (http://www.cbs.dtu. $\mathrm{dk} /$ services/SignalP/). The deduced mature protein of PoMan5A contained of 426 residues with a calculated molecular mass of $45.8 \mathrm{kDa}$ and a theoretical pI of 5.09 (http://web.expasy.org/compute_pi/). The deduced amino acid sequence of PoMan5A showed the highest identity of $100 \%$ with the putative endo-1,4- $\beta$-mannanase from Penicillium oxalicum 114-2 (EPS31069). PoMan5A contained an $\mathrm{N}$-terminal fungal cellulose binding domain and a glycosyl hydrolase family 5 domain. After multiple sequence alignments with other GH5 endo-1,4- $\beta$-mannanase amino acid sequences, the two catalytic glutamates (Glu 320 and Glu 391) are located in highly conserved regions of the active site in PoMan5A. Several amino acid residues, Arg169, Trp279, Asn283, His357, and Tyr393 are conserved in PoMan5A and other fungal GH5 endo- $\beta-1$, 4-mannanases (Figure 1). The nucleotide sequence of poMan5A was deposited into GeneBank under accession number KF233753. 


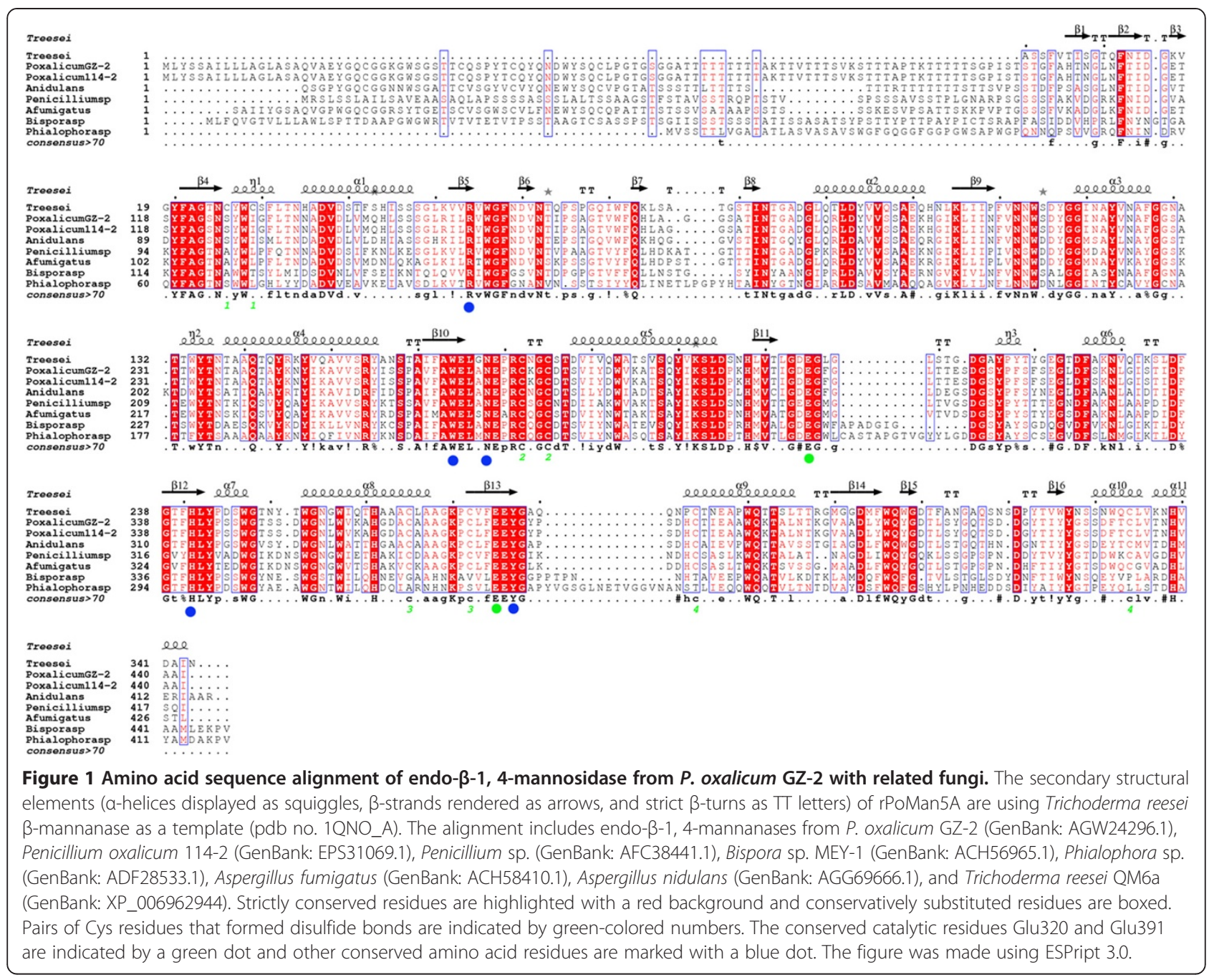

Heterologous expression and purification of the $P$. oxalicum endo-1,4- $\beta$-mannanase

The gene expression vector $p P I C-\operatorname{man} 5 A$ was successfully constructed for use in this study. In this recombinant plasmid, cDNA fragments were fused with the $\alpha$-factor signal sequence at its $\mathrm{N}$-terminus allowing secretion of enzyme into the liquid culture that was expressed under the control of the AOX1 promoter. The resulting plasmid was then transformed into Pichia pastoris by electroporation. After transformation and screening on plates containing Zeocin in increasing concentrations, 20 transformants showing robust antibiotic-resistance were further evaluated for their ability to secrete endo-1,4- $\beta$-mannanase in a small-scale liquid fermentation. One transformant with the highest enzyme activity was used to produce endo$1,4-\beta$-mannanase in a $1 \mathrm{~L}$ Erlenmeyer flask induced by $1 \%$ methanol at $28^{\circ} \mathrm{C}$ for 7 days. The highest extracellular endo-1,4- $\beta$-mannanase activity $\left(84.4 \mathrm{U} \mathrm{mL}^{-1}\right)$ was obtained after a 6 day incubation at $28^{\circ} \mathrm{C}$. SDS-PAGE analysis of the culture supernatants of the induction period from 1 to 7 day showed an apparent protein band (Figure 2A) corresponding to endo-1,4- $\beta$-mannanase activity in the zymogram analysis (Figure $2 \mathrm{~B}$ ). No endo-1,4- $\beta$-mannanase activity was detected in the culture medium of the control strain (transformed with pPICZ $\alpha \mathrm{A}$ ) under the same culture conditions. The recombinant endo-1,4- $\beta$-mannanase was purified to electrophoretic homogeneity through Ni-NTA chromatography. After Ni-NTA purification, a 4.5-fold purification was achieved with 56\% recovery. The purified rPoMan5A showed a single band with an apparent molecular mass of $61.6 \mathrm{kDa}$ by SDS-PAGE (Figure 3).

\section{Biochemical properties of the purified recombinant endo-1,4- $\beta$-mannanase \\ Effect of temperature and $\mathrm{pH}$ on rPoMan5A activity and stability}

The effects of temperature and $\mathrm{pH}$ on rPoMan5A activity were investigated using locust bean gum as the substrate. The rPoMan5A showed optimal activity at the 


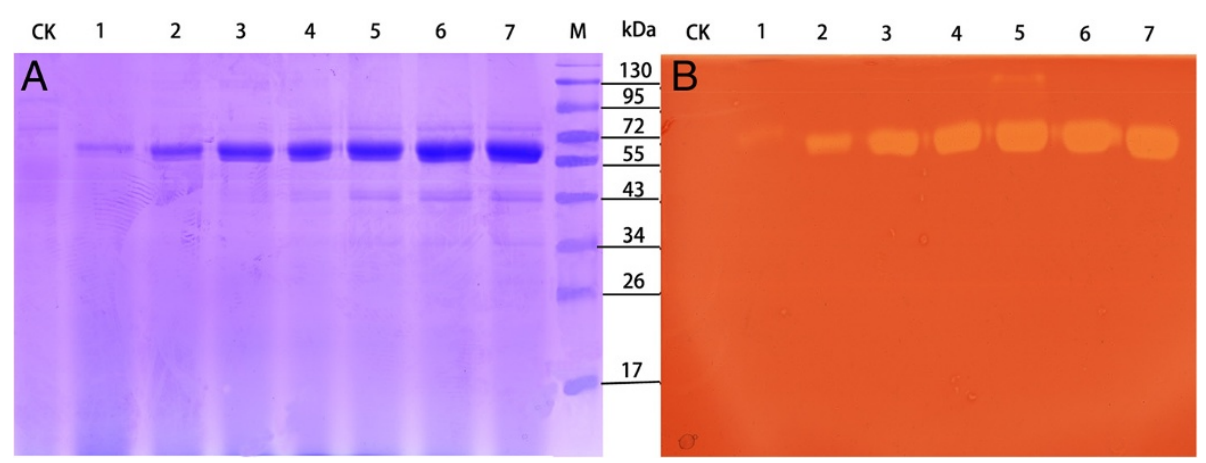

Figure 2 SDS-PAGE and zymography analysis of culture supernatants from recombinant Pichia pastoris during 7-day fermentation.

SDS-PAGE (A) and zymography (B) of secreted proteins produced by recombinant Pichia pastoris fusing the $P$. oxalicum GZ-2 endo- $\beta-1,4-$-mannosidase gene. Lane CK: Pichia pastoris GS1 15 with the empty pPICZaA after induction for 4 days; Lane 1-7: culture supernatant after induction for 1, 2, 3, 4, 5, 6, and 7 days; Lane M: protein molecular mass makers. Twenty microliters of culture supernatants was added into each gel lane.

temperature of $80^{\circ} \mathrm{C}$ and $\mathrm{pH} 3.0-4.0$ and exhibited over $50 \%$ activity in temperatures ranging from $40^{\circ} \mathrm{C}$ to $90^{\circ} \mathrm{C}$ (Figure 4A). The thermal stability profiles showed that $\mathrm{rPoMan} 5 \mathrm{~A}$ was stable at temperatures below $70^{\circ} \mathrm{C}$ (Figure 4B). Almost no enzyme activity ( $>98 \%)$ was lost after $1 \mathrm{~h}$ incubation at $60^{\circ} \mathrm{C}$, and the half-life at this temperature was $58 \mathrm{~h}$. At $70^{\circ} \mathrm{C}$, the half-life of the enzyme was only $21 \mathrm{~min}$. The rPoMan5A retained more than $96 \%$ of its maximal activity at pH 2.0 (Figure 5). The $\mathrm{pH}$ stability profiles showed that the enzyme was highly stable within a broad range of $\mathrm{pH}$ values, ranging from 3.0 to 7.0 (Figure 5).

\section{Effect of metal ions and chemical reagents on endo-1, 4- $\beta$-mannanase activity}

The presence of most metal ions at $1 \mathrm{mM}$ or $10 \mathrm{mM}\left(\mathrm{Ca}^{2+}\right.$, $\mathrm{Cd}^{2+}, \mathrm{Cr}^{3+}, \mathrm{Co}^{2+}, \mathrm{Ba}^{2+}, \mathrm{Mg}^{2+}, \mathrm{Mn}^{2+}, \mathrm{Ni}^{2+}, \mathrm{Li}^{+}$and $\left.\mathrm{Fe}^{2+}\right)$ had little or no effect on the activity of rPoMan5A. At the high concentrations of $\mathrm{Cu}^{2+}$ and $\mathrm{Fe}^{3+}(10 \mathrm{mM})$, the activity of rPoMan5A was reduced to almost $50 \%$. The whole activity of rPoMan5A was lost in the presence of $10 \mathrm{mM} \mathrm{Hg}^{2+}$ (Table 1). $\beta$-Mercaptoethanol (1 mM, 76.2\%), dithiothreitol (DTT) $(1 \mathrm{mM}, 81.2 \%)$ and $0.1 \%$ SDS (92.0\%) partially influenced the rPoMan5A activity, while $0.1 \%$ Triton-X 100 strongly decreased the rPoMan5A activity (25\%).

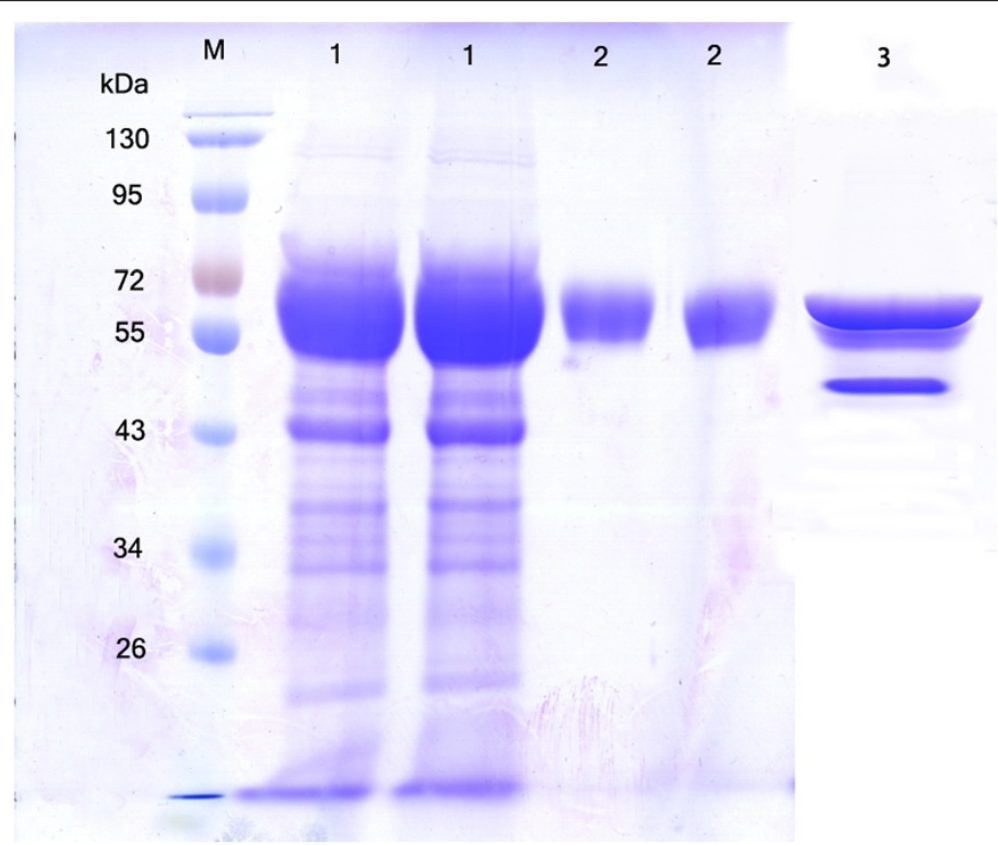

Figure 3 SDS-PAGE analysis of the deglycosylation of $\mathbf{r P o M a n} 5 \mathrm{~A}$ with Endo $\mathrm{H}_{\mathbf{f}}$ and purified $\mathbf{r P o M a n} 5 \mathrm{~A}$ fractions. Lane 1 , concentrated proteins from an ammonium sulfate precipitation; Lane 2, purified rPoMan5A; Lane 3, deglycosylated rPoMan5A after endo $\mathrm{H}_{\mathrm{f}}$ treatment; Lane M, protein molecular mass makers. 

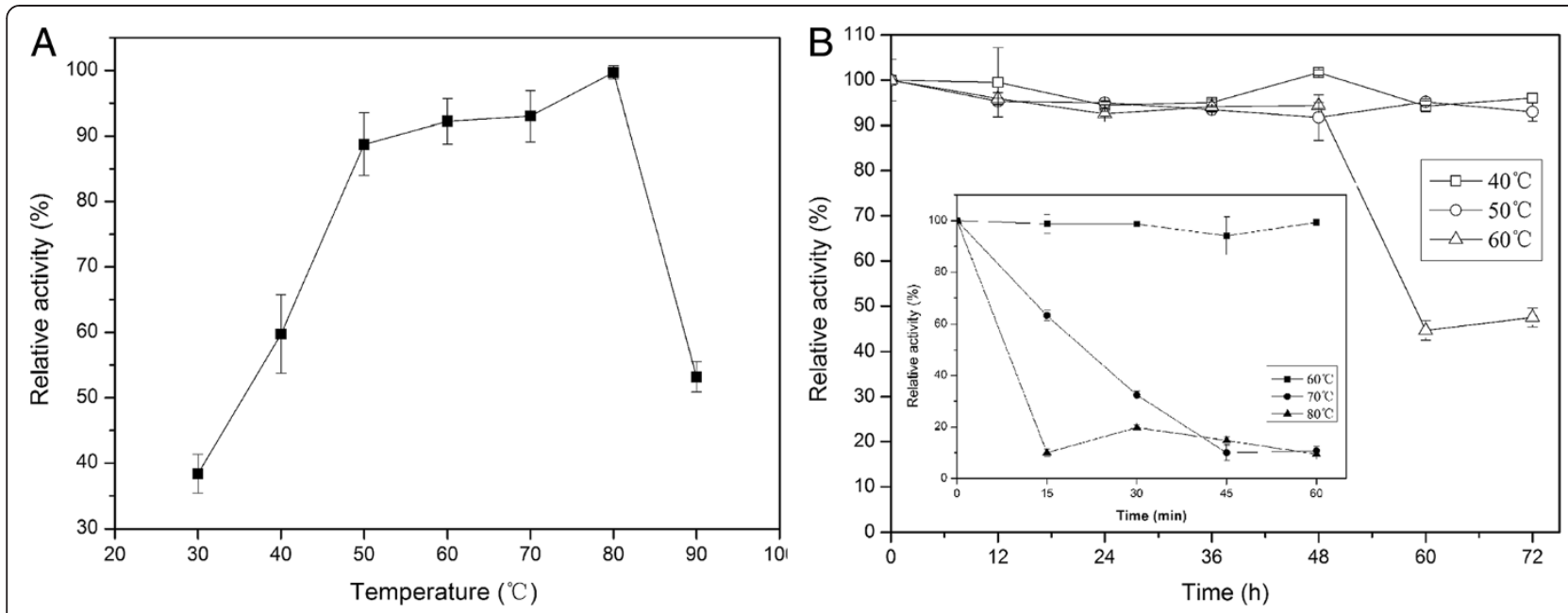

Figure 4 Optimal temperature (A) and thermostability (B) of purified rPoMan5A. The optimal temperature for endo- $\beta-1,4-m a n n o s i d a s e$ activity was measured at different temperatures using $0.5 \%$ locust bean gum as the substrate. The thermal stability was evaluated as the relative residual activity after incubation without the substrate at different temperatures at $\mathrm{pH}$ 4.0. Data are the mean of three replicates, and bars indicate the standard deviation of three replicates.

\section{Substrate specificity and kinetics parameters}

The rPoMan5A exhibited the highest activity with locust bean gum (100\%) and lower activity for guar gum (30.0\%). There was no enzyme activity with sodium carboxymethyl cellulose, filter paper, and beechwood xylan as substrate. The $K_{m}$ and $V_{\max }$ values of purified rPoMan5A were $7.6 \mathrm{mg} \mathrm{mL}^{-1}$ and $1425.4 \mathrm{U} \mathrm{mg}^{-1}$ for locust bean gum, $2.1 \mathrm{mg} \mathrm{mL}^{-1}$ and $154.8 \mathrm{U} \mathrm{mg}^{-1}$ for konjac glucomannan, and $2.3 \mathrm{mg} \mathrm{mL}^{-1} 18.9 \mathrm{U} \mathrm{mg}^{-1}$ for guar gum, respectively (Table 2).

\section{Analysis of the hydrolysis products}

The hydrolysis products of locust bean gum, konjac glucomannan, and guar gum by rPoMan5A were analyzed by thin-layer chromatography (TLC). As shown in Figure 6, the rPoMan5A hydrolyzed various types of mannan polymers, such as galacto-and glucomannans and released various mannose and manno-oligosaccharides. The hydrolysis of locust bean gum yielded mannobiose (M2), mannotriose (M3), and mannopentaose (M5), and other unidentifiable oligosaccharides as the main products

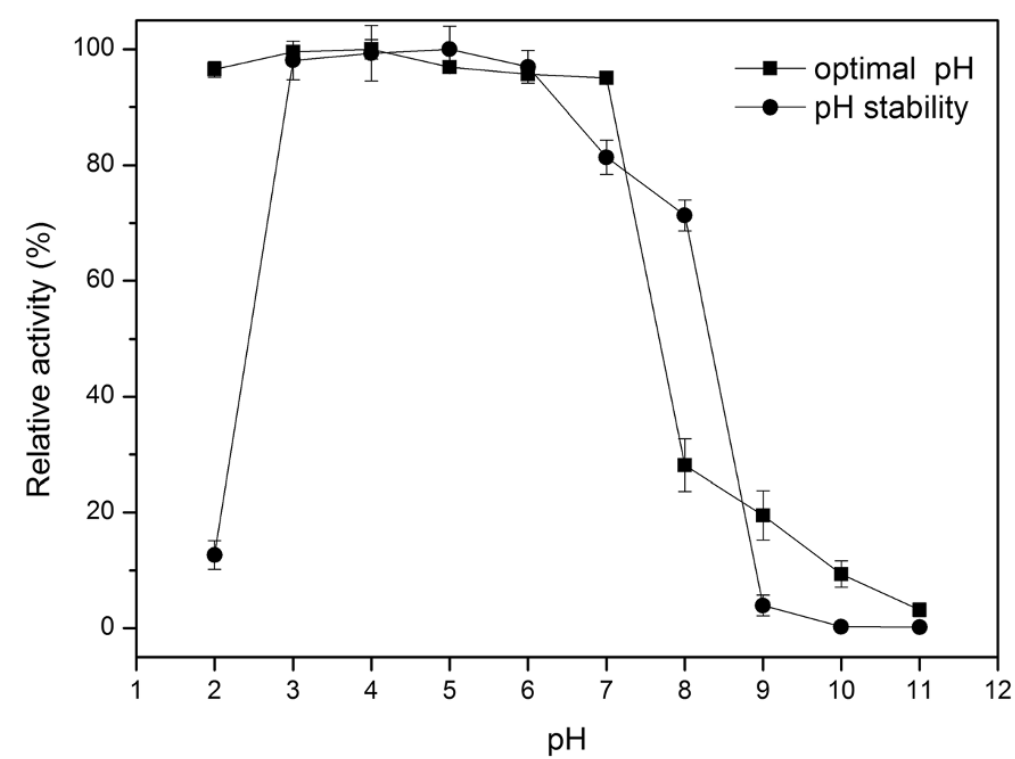

Figure 5 Optimal pH and pH stability of purified rPoMan5A. The influence of pH on enzyme activity was determined in different $50 \mathrm{mM}$ buffers using $0.5 \%$ locust bean gum as the substrate. The $\mathrm{pH}$ stability was shown as the remaining activity after incubation for $30 \mathrm{~min}$ at $60^{\circ} \mathrm{C}$ in buffers at various $\mathrm{pH}$ without the substrate. Data are the mean of three replicates, and bars indicate standard deviation of three replicates. 


\begin{tabular}{lll}
$\begin{array}{l}\text { Table } \mathbf{1} \text { Effects of metal ions on the activity of the } \\
\text { rPoMan5A }\end{array}$ \\
\hline $\begin{array}{ll}\text { Metal } \\
\text { ions }\end{array}$ & Relative activity (\%) \\
\cline { 2 - 3 } $\mathbf{1} \mathbf{~ m M}$ & $\mathbf{1 0 ~ \mathbf { ~ M }}$ \\
\hline Control & $100.0 \pm 2.7$ & $98.6 \pm 0.9$ \\
$\mathrm{Ca}^{2+}$ & $95.2 \pm 0.3$ & $105.1 \pm 2.7$ \\
$\mathrm{Cd}^{2+}$ & $97.2 \pm 0.7$ & $101.1 \pm 0.3$ \\
$\mathrm{Cr}^{3+}$ & $100.9 \pm 0.3$ & $94.0 \pm 0.2$ \\
$\mathrm{Co}^{2+}$ & $100.0 \pm 1.4$ & $57.1 \pm 3.8$ \\
$\mathrm{Cu}^{2+}$ & $86.5 \pm 3.0$ & $104.6 \pm 0.9$ \\
$\mathrm{Ba}^{2+}$ & $98.6 \pm 1.7$ & $103.6 \pm 0.8$ \\
$\mathrm{Mg}^{2+}$ & $97.6 \pm 0.2$ & $99.6 \pm 2.4$ \\
$\mathrm{Mn}^{2+}$ & $85.4 \pm 1.3$ & $98.7 \pm 5.6$ \\
$\mathrm{Ni}^{2+}$ & $95.4 \pm 1.5$ & $105.7 \pm 3.2$ \\
$\mathrm{Li}^{+}$ & $97.1 \pm 1.0$ & $103.5 \pm 2.0$ \\
$\mathrm{Fe}^{2+}$ & $97.1 \pm 1.0$ & $50.0 \pm 2.8$ \\
$\mathrm{Fe}^{3+}$ & $64.9 \pm 3.3$ & $0.0 \pm 0.0$ \\
$\mathrm{Hg}^{2+}$ & $64.9 \pm 3.3$ & \\
\hline $\mathrm{Da}^{2+}$ &
\end{tabular}

Data are the mean \pm standard deviation of three repeats.

(Figure 6A). The degradation of konjac glucomannan resulted in the formation of a mixture of mannose and manno-oligosaccharides (Figure 6B). Mannotriose (M3), mannotetraose (M4), and mannopentaose (M5) were the major products of hydrolysis of guar gum by rPoMan5A (Figure 6C). The release of mannose required at least 4 hours when locust bean gum were used as the substrate, but for konjac glucomannan and guar gum, there is already slight band after $5 \mathrm{~min}$.

\section{Discussion}

Our previous study demonstrated that the P. oxalicum GZ-2 is a robust hemicellulase-producing fungus during submerged fermentation used agricultural residues as carbon source [13]. In this study, a new endo-1,4- $\beta$ mannanase gene from $P$. oxalicum GZ-2 was cloned and successfully expressed in Pichia pastoris. The gene sequence of endo-1,4- $\beta$-mannosidase showed highest sequence similar (74\%) to mannanase from Aspergillus aculeatus base on BLAST on NCBI (http://blast.ncbi. nlm.nih.gov/Blast.cgi). The amino acid sequence of endo-1,4- $\beta$-mannanase from P. oxalicum GZ-2 has $100 \%$ identity with the putative endo-1,4- $\beta$-mannanase from Penicillium oxalicum 114-2, followed by $71 \%$ with the likely endo-1,4- $\beta$-mannosidase from the Penicillium roqueforti. An abundance of endo-1,4- $\beta$-mannanases from other fungi genera such as Aspergillus and Trichoderma have previously been cloned and expressed in Pichia pastoris $[5,7,14,15]$. However, only few endo-1,4- $\beta$-mannanases from Penicillium genera have been cloned and expressed to date [16-18].

Based on amino acid sequence similarities, endo-1,4$\beta$-mannanase has been classified into three families of glycoside hydrolases (family 5, 26, and 113, http://www. cazy.org). Most of fungal $\beta$-mannanases are predominantly belonging to family 5 , and the bacterial $\beta$-mannanases belong to GH 5 or GH 26 [17]. Homology amino acid sequence comparison with other known fungal $\mathrm{GH} 5$ $\beta$-mannanases showed that several catalytic active-sites are highly conserved. These features demonstrate that the rPoMan5A is a member of the GH5. A cellulose-binding domain (CBD) was identified in rPoMan5A at the $\mathrm{N}$ terminus when aligned with available protein sequences from the NCBI databases. In GH5 fungal endo-1,4- $\beta$-mannanases, a CBD has been found at either the C-, or $\mathrm{N}$-terminus of some enzymes that contained a catalytic domain (CD). For example, the CBD of Trichoderma reesei endo-1,4- $\beta$-mannanase (amino acid position 373-410) [19] and Phanerochaete chrysosporium (amino acid position 25-53) [20] are located at the $\mathrm{C}$ terminus and $\mathrm{N}$ terminus, respectively. The CBD play a very important role in the endo-1,4- $\beta$-mannanases activity. The CBD of Trichoderma reesei endo-1,4- $\beta$-mannanase has the ability to bind cellulose and increase the hydrolysis rate [21]. The endo-1,4- $\beta$-mannanase of Aspergillus usamii YL-01-78 consists of only a catalytic domain (CD), while a fusion of CBD from the Trichoderma reesei cellobiohydrolase into this enzyme could improve its catalytic activity and/or thermostability [22]. However, the mechanism of CBDs in catalysis still needs to be explored.

When the recombinant yeast was incubated at $28^{\circ} \mathrm{C}$ in a 1 L shake flask culture, a high level expression of endo-1,4- $\beta$-mannanase was obtained in Pichia pastoris $\left(262 \mathrm{mg} \mathrm{L}^{-1}\right)$. In comparison with other fungal endo-1,4$\beta$-mannanase expression levels in yeast, like Bispora sp. MEY-1 MAN5A expressed $148 \mathrm{mg} \mathrm{L}^{-1}$ [23], A. niger endo-1,4- $\beta$-mannanase expressed $243 \mathrm{mg} \mathrm{mL}^{-1}$ [5], and Trichoderma reesei endo-1,4- $\beta$-mannanase expressed $150 \mathrm{mg} \mathrm{L}^{-1}$ [19], the yield of rPoMan5A was superior. The crude supernatant of Pichia pastoris showed good activity (84.4 $\mathrm{U} \mathrm{mL}^{-1}$ ) and high specific activity (420.9 $\mathrm{U} \mathrm{mg}^{-1}$ ), as

Table 2 Kinetic parameters of rPoMan5A for the hydrolysis of various mannans

\begin{tabular}{lllll}
\hline Substrate & $\boldsymbol{V}_{\boldsymbol{m a x}}\left(\mathbf{U} \mathbf{~ m}^{-\mathbf{1}}\right)$ & $\boldsymbol{K}_{\boldsymbol{m}}\left(\mathbf{m g ~ m L}^{-\mathbf{1}}\right)$ & $\mathbf{k}_{\mathrm{cat}}\left(\mathbf{s}^{-\mathbf{1}}\right)$ & $\mathbf{k}_{\mathrm{cat}} / \boldsymbol{K}_{\boldsymbol{m}}\left(\mathrm{mL}_{\mathbf{~ m g}} \mathbf{- 1}^{\mathbf{- 1}}\right)$ \\
\hline Locust bean gum & 1425.5 & 7.6 & 1463.5 & 192.6 \\
Konjac glucomannan & 154.8 & 2.1 & 158.9 & 75.7 \\
Guar gum & 18.9 & 2.3 & 19.4 & 8.4 \\
\hline
\end{tabular}



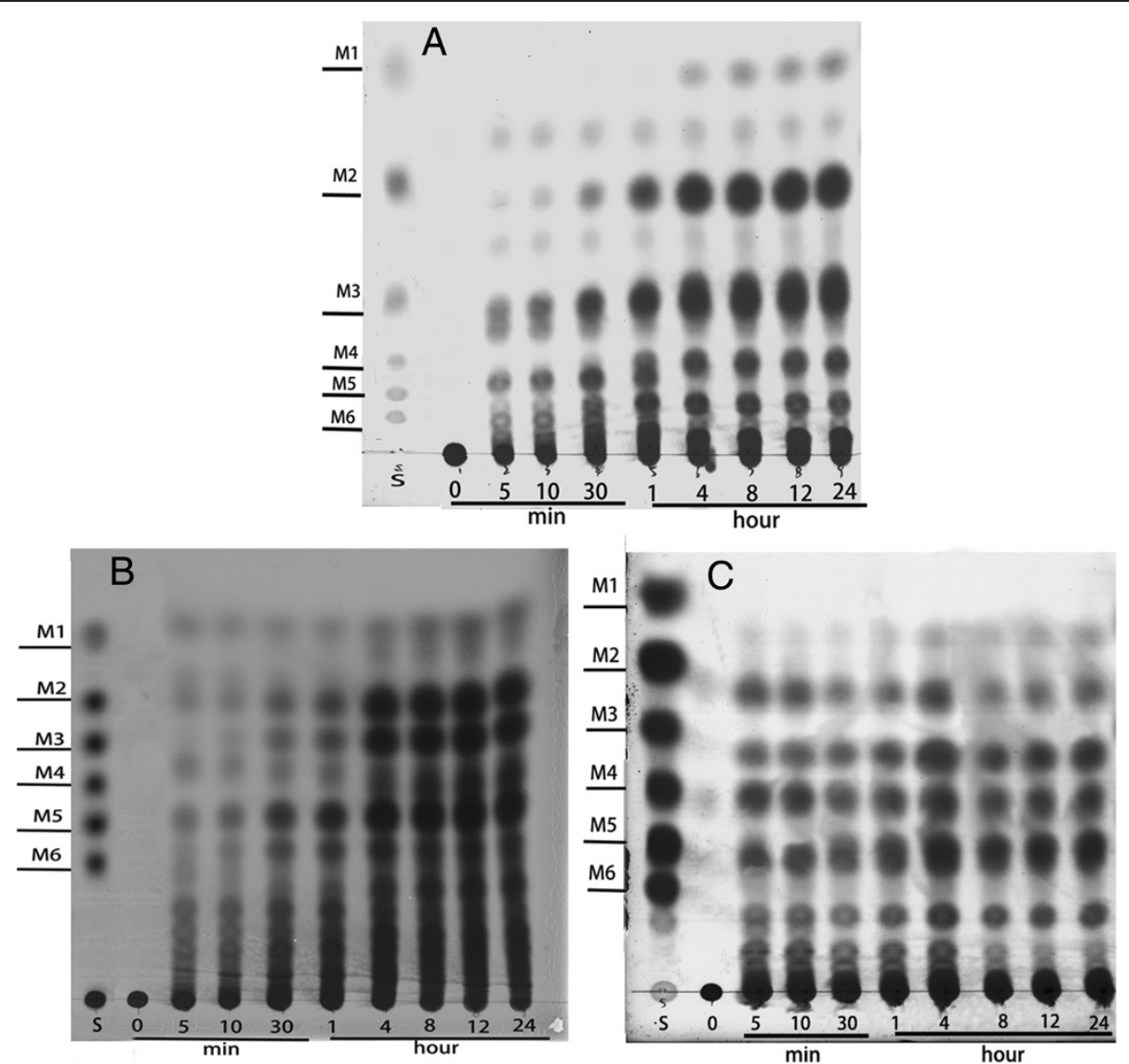

Figure 6 TLC analysis of the products after hydrolysis of various mannan polymers (0.5\%) by rPoMan5A. The purified enzyme rPoMan5 A and $0.5 \%$ various substrates (A: locust bean gum, B: konjac glucomannan, $\mathbf{C}$ : guar gum) were incubated in $50 \mathrm{mM}$ acetate buffer ( $\mathrm{pH} 4.0)$ at $60^{\circ} \mathrm{C}$. Incubation times (hour or minute) are indicated. S, mannose and manno-oligosaccharides were used as standards.

well as high purity of the crude enzymes. Since cultivation experiments were performed in shake flasks which more or less limited the growth of yeast, it will result in considerably higher enzyme yields in a fermenter under controlled and optimized conditions [24]. Therefore, those features suggested the enzyme has great potential for large-scale production.

The purified rPoMan5A showed a single $61.6 \mathrm{kDa}$ protein band on an SDS-PAGE (Figure 3), higher than that of the calculated molecular mass of the mature peptide $(45.8 \mathrm{kDa})$. This may be due to the glycosylation of the expressed protein in Pichia pastoris. Two putative glycosylation sites in the PoMan5A amino acid sequence $\left({ }^{127} \mathrm{NFTI}\right.$ and $\left.{ }^{229} \mathrm{NWSD}\right)$ were predicted by the NetNGlyc 1.0 Server (http://www.cbs.dtu.dk/services/NetNGlyc/). The decrease in the molecular mass of rPoMan5A was verified by deglycosylation with Endo $\mathrm{H}_{\mathrm{f}}$ on an SDSPAGE (Figure 3). Many researchers had observed that the glycosylation of recombinant endo-1,4- $\beta$-mannanase in Pichia pastoris was able to obviously increase the molecular mass, such as endo-1,4- $\beta$-mannanase from Aspergillus niger BK01 [5], Man5C1 from Penicillium pinophilum C1 [16], and Anman5A from Aspergillus niger LW-1 [7].

The optimal temperature and $\mathrm{pH}$ for the rPoMan5A activity was $80^{\circ} \mathrm{C}$ and $\mathrm{pH}$ 3.0-4.0, respectively. For most fungal endo-1,4- $\beta$-mannanases the optimal temperature and $\mathrm{pH}$ are between $40-70^{\circ} \mathrm{C}$ and $\mathrm{pH} 4.0-6.0$, respectively [25], such as endo-1,4- $\beta$-mannanase from Rhizomucor miehei (optimal temperature $55^{\circ} \mathrm{C}$ and $\mathrm{pH}$ 7.0) [26], MANI and MANII from Aspergillus fumigatus IMI $385708\left(60^{\circ} \mathrm{C}\right.$ and $\mathrm{pH}$ 4.5) [27], endo-1,4- $\beta$-mannanase from $P$. oxalicum SO $\left(60^{\circ} \mathrm{C}\right.$ and $\left.\mathrm{pH} 5.0\right)$ [28], endo-1,4- $\beta$-mannanase from A. niger $\mathrm{BK} 01\left(80^{\circ} \mathrm{C}\right.$ and $\left.\mathrm{pH} 4.5\right)$ [5], and $\mathrm{rMan} 5 \mathrm{C} 1$ from P. pinophilum $\mathrm{C} 1\left(70^{\circ} \mathrm{C}\right.$ and $\left.\mathrm{pH} 4.0\right)$ [16]. However, the rPoMan5A possesses some superior properties compared to these fungal endo-1,4- $\beta$-mannanases, such as a long half-life $(58 \mathrm{~h})$ at high temperatures $\left(60^{\circ} \mathrm{C}\right)$ and a wide range of $\mathrm{pH}$ adaptability ( $\mathrm{pH}$ 2.0-7.0) and stability $(\mathrm{pH}$ 3.0-7.0). Most fungal endo-1,4- $\beta$-mannanases were stable at temperatures below $50^{\circ} \mathrm{C}$, such as rMan5F63 from Penicillium freii F63 (half-life of $30 \mathrm{~min}$ at $60^{\circ} \mathrm{C}$ ) [18], recombinant man5XZ7 from thermophilic fungus 
Thielavia arenaria XZ7 (half-life of $30 \mathrm{~min}$ at $60^{\circ} \mathrm{C}$ ) [29], and recombinant Man5XZ3 from Aspergillus nidulans XZ3 (half-life of $240 \mathrm{~min}$ at $60^{\circ} \mathrm{C}$ ). Although rPoMan5A was unstable (less than $13 \%$ residual activity after incubation $30 \mathrm{~min}$ at $\mathrm{pH} 2.0$ ) at $\mathrm{pH}$ 2.0, it exhibited 96.3\% activity at such low $\mathrm{pH}$ (10 min assay). In comparison, the endo-1,4- $\beta$-mannanase from Aspergillus niger BK01 showed only $20 \%$ activity at $\mathrm{pH} 2.5$ [5], and rMan5C1 from $P$. pinophilum $\mathrm{C} 1$ likewise lost $80 \%$ activity at $\mathrm{pH} 2.0$ [16]. Many industrial bioprocesses involving enzymes depend on the use of low $\mathrm{pH}$ conditions to prevent contamination by other microbes. Therefore, rPoMan5A has the potential to be used in such processes, where fermentation requires low $\mathrm{pH}$ conditions. At its optimal catalytic temperature $\left(80^{\circ} \mathrm{C}\right)$, rPoMan5A was unstable. This characteristic is similar to many other reported fungal endo-1,4$\beta$-mannanases [18]. The enzyme binding to the substrate could partially stabilize the enzyme conformation, and having no substrate to bind resulted in the loss of enzymatic activity during a thermostability assay [16]. Therefore, endo-1,4- $\beta$-mannanase showed acidophilic and thermostable characteristics, features that not only increase the rate of hydrolysis but also reduce cost of production in the food industry. Consistent with our results, $\mathrm{Hg}^{2+}$ has been shown to strongly inhibit other endo-1,4- $\beta$-mannanases $[7,26]$. Inhibition of rPoMan5A activity by $\mathrm{Hg}^{2+}$ may be due to the oxidation of specific residues containing sulfhydryl groups such as cysteine. The mature protein of rPoMan5A has 10 cysteine residues. The influence of $\mathrm{Fe}^{3+}$ on rPoMan5A is similar to other endo-1,4- $\beta$-mannanases $[15,30]$. The activity of rPoMan5A in $1 \mathrm{mM}$ reducing agents such as $\beta$-Mercaptoethanol and DTT as well as $0.1 \%$ SDS remained above $75 \%$. SDS has been shown to almost completely inhibit endo-1,4- $\beta$-mannanase activity $[11,16,23]$.

The rPoMan5A exhibited different activity against various substrates, such as locust bean gum (100\% activity), konjac glucomannan $(73.6 \%$ activity), and guar gum (30.0\% activity). RmMan5A from Rhizomucor miehei displayed a same activity order: locust bean gum $>$ konjac glucomannan > guar gum, when used to hydrolyze various mannans [26]. Locust bean gum is a galactomannan with a high mannose/galactose ratio of 4:1; konjac glucomannan is a glucomannan containing a mannose/glucose ratio of $3: 1$ and guar gum is a galactomannan with mannose/ galactose ratio of $2: 1$ [31]. The structural differences between these three mannan polymers may lead to various enzymatic activities, when they are used as substrates. There was no enzyme activity detected on (hemi) cellulosic substrates, such as beechwood xylan, CMC-Na, and filter paper. The cellulase-free characteristic of rPoMan5A is in agreement with the most of fungal endo- $1,4-\beta$-mannanases [5,26,29]. The cellulase-free characteristic of rPoMan5A is valuable for the applications involving bleaching pulp and paper [10]. The $K_{m}$ value of rPoMan5A for locust bean gum $\left(7.6 \mathrm{mg} \mathrm{mL}^{-1}\right)$ was close to the values obtained for some other fungal endo-1,4- $\beta$ mannanases, such as rMan5F63 from Penicillium freii F63 (7.8 $\mathrm{mg} \mathrm{mL}^{-1}$ ) [18], rMan5C1 from P. pinophilum C1 (5.6 $\mathrm{mg} \mathrm{mL}^{-1}$ ) [16], and Man5XZ7 from Thielavia arenaria XZ7 $\left(5.3 \mathrm{mg} \mathrm{mL}^{-1}\right)$ [29]. The $K_{m}$ value of rPoMan5A for konjac glucomannan and guar gum was 3-fold lower than for locust bean gum.

Most endo-1,4- $\beta$-mannanases degrade the backbone of various mannan polysaccharides to produce primarily mannotriose and mannobiose with no mannose. For example, the hydrolysis by endo-1,4- $\beta$-mannanase from Aspergillus niger BK01 showed that mannobiose was the main product and mannose was not liberated using locust bean gum as substrate [5]. However, some endo1,4- $\beta$-mannanases also released mannose from mannan polymers $[18,23]$. In this study, the endo-1,4- $\beta$-mannanases whether liberate mannose or not, were dependent on different substrates and hydrolysis time. Similar enzymatic properties were reported for RmMan5A from Rhizomucor miehei [26]. The action of the rPoMan5A on different substrates indicated that its function was not only as endo- $\beta-1,4-$ mannanase but also as a $1,4-\beta$ mannosidase. An abundance of manno-oligosaccharides primarily containing various oligosaccharides (M2 to M6) was obtained from hydrolyzing the inexpensive and widely available locust bean gum and konjac glucomannan by rPoMan5A. Because monogastric animals cannot effectively digest the mannans and galactomannans into nutritional components, the incorporation of endo-1,4$\beta$-mannanase into their diets would help them to more easily digest the nutritional elements. Thus, rPoMan5A has a potential application in the food/feed industries. Although the enzyme rPoMan5A exhibited attractive biochemical properties like acid-resistant and thermostability, but there is need to explain the mechanisms of its superior properties. The molecular enzyme engineering should be considered to improve the catalytic efficiency and characteristics in the further studies.

\section{Conclusion}

In this study, a new gene encoding a GH5 acidophilic thermostable endo-1,4- $\beta$-mannanase from Penicillium oxalicum was cloned and expressed in Pichia pastoris. High stability across a broad acidic $\mathrm{pH}$ range and thermostability make rPoMan5A better suited for many industrial applications in the food/feed and paper/pulp industries compared to most other fungal endo-1,4- $\beta$-mannanases.

\section{Methods}

\section{Plasmids, strains and culture conditions}

The P. oxalicum GZ-2 referred to in this study was isolated and identified as previously reported [13] and has 
been deposited at the China General Microbiological Culture Collection Center (CGMCC 7527). Escherichia coli strain TOP 10 (Invitrogen, San Diego, CA) grown in Luria Bertani (LB) medium at $37^{\circ} \mathrm{C}$ was used as the host cell for plasmid cloning and propagation of the recombinant expression pPICZ $\alpha$ A vector. Pichia pastoris GS115 (Invitrogen, San Diego, CA) was used for heterologous protein expression. All media and protocols for Pichia pastoris are described in the Pichia expression manual (Invitrogen, San Diego, CA). Manno-oligosaccharides were purchased from Megazyme (Bray, Ireland). P. oxalicum GZ-2 was maintained and cultured according previously study [32]. Pichia pastoris GS115 was cultivated at $30^{\circ} \mathrm{C}$ in yeast extract peptone dextrose (YPD) medium (1\% yeast extract, $2 \%$ tryptone, and $2 \%$ dextrose).

Total RNA isolation, CDNA synthesis and cloning of the endo-1,4- $\beta$-mannanase gene

The P. oxalicum GZ-2 strain was grown at $30^{\circ} \mathrm{C}$ in a 250 $\mathrm{mL}$ shaker flask containing $50 \mathrm{~mL}$ basal culture medium in a shaking incubator using $2 \%$ corncob powder as the sole carbon source. After a $72 \mathrm{~h}$ growth period, the mycelium was harvested for total RNA isolation. The genomic DNA of P. oxalicum GZ-2 was extracted as described by Möller et al. [33]. RNA isolation and cDNA synthesis was performed as previously reported [32]. The degenerate primers manA-df and manA-dr were used (Table 3), which were designed using the iCODEHOP (http://blocks.fhcrc.org/codehop.html) program based on the multiple sequence alignment of homologous amino acid sequences using the ClustalW2 program. The partial sequence of $P$. oxalicum GZ-2 endo-1,4- $\beta$-mannanase gene was amplified by polymerase chain reaction (PCR) using the degenerate primers. To obtain the full-length gene, self-formed adaptor PCR (SEFA-PCR) was performed to amplify the 5'-end and the 3'-end of poman $5 \mathrm{~A}$ according to the protocol developed by Wang et al. [34] with the primers listed in Table 3. By aligning the sequences of the 5'-end and 3'-end PCR products, the fulllength cDNA sequence of poman $5 A$ was deduced and obtained through RT-PCR using the following specific primers: manA-f and manA-r. The PCR fragment was purified and ligated into the $\mathrm{pMD}-19 \mathrm{~T}$ vector and was designated $\mathrm{pMD}-\mathrm{man} 5 \mathrm{~A}$. The $\mathrm{cDNA}$ encoding the mature $P$. oxalicum GZ-2 endo-1,4- $\beta$-mannanase gene was PCR amplified with PrimeSTAR ${ }^{\mathrm{m}}$ HS DNA Polymerase (Takara, Dalian, China) using the recombinant plasmid pMD-man5A as a template, with specific primers manA-ef including an EcoRI site, and manA-er including an XbaI site. After digestion with EcoRI and $X b a \mathrm{I}$, The DNA insert was ligated into the pPICZ $\alpha \mathrm{A}$ vector downstream of the $\alpha$-factor signal peptide sequence. Proper construction was confirmed by restriction digestion and DNA sequencing and was designated as pPIC-man5A. The nucleotide sequence of poMan5A has been deposited in the GeneBank under accession number KF233753.

\section{Expression of the endo-1,4- $\beta$-mannanase gene in Pichia pastoris in shaken flasks}

The recombinant plasmid $p P I C-m a n A$ was linearized with PmeI (New England BioLabs, Beverly, MA, USA), and then transformed into Pichia pastoris GS115 by electroporation (Gene Pulser Xcell ${ }^{\mathrm{TM}}$ Electroporation System, BioRad, Hercules, CA, USA) according to the manufacturer's instructions. The control was transformed with empty pPICZ $\alpha \mathrm{A}$ at same condition. The transformants were plated on YPDS plates (1\% yeast extract, $2 \%$ tryptone, $2 \%$ dextrose, $1 \mathrm{M}$ sorbitol, $100 \mu \mathrm{g} \mathrm{mL} \mathrm{m}^{-1}$ Zeocin, and 2\% agar)

Table 3 Primers used in this study

\begin{tabular}{|c|c|c|c|}
\hline Primer name & Primer purpose & Primer sequence & Size (bases) \\
\hline manA-df & Degenerate primers & CGGGTCTGGGGCTTYAAYGAYGT & 23 \\
\hline manA-dr & & GTG CCGTAGTAGATGGTRTTNCCRTCRT & 28 \\
\hline manA-3-sp3 & Amplify gene of the 3 '-end by SEFA-PCR & ACTTCCATCTGTACNNNNNNNNNTGTGAG & 30 \\
\hline manA-3-sp2 & & TGACGACCGAGTCTGACGGAAGCTA & 25 \\
\hline manA-3-sp1 & & CTGGGTCAAGGCGACTAGCCAATAT & 25 \\
\hline manA-5-sp3 & Amplify gene of the $5^{\prime}$-end by SEFA-PCR & GTGTTGATGGTGGCGNNNNNNNNNGCAAGA & 30 \\
\hline manA-5-sp2 & & GGAGATGAGATGTACCGCGAAACCA & 25 \\
\hline manA-5-sp1 & & CCATGTGCTTCGGGTCGAGTGATTT & 25 \\
\hline manA-f & cDNA cloning primers & ATGACATTGGGATTGACTCAGACGA & 25 \\
\hline manA-r & & TCAGATCGCAGCGACATGATT & 21 \\
\hline manA-ef & Specific expression primers & CGGAATTCCAGGTGGCGGAATATGGCCAGTGT & 32 \\
\hline manA-er & & GCTCTAGATAGATCGCAGCGACATGATTCGTCACCA & 36 \\
\hline $5^{\prime} \mathrm{AOX}$ & Confirmed primers & GACTGGTTCCAATTGACAAGC & 21 \\
\hline $3^{\prime} \mathrm{AOX}$ & & GCAAATGGCATTCTGACATCC & 21 \\
\hline
\end{tabular}


and incubated at $30^{\circ} \mathrm{C}$ for 2-3 days until colonies appeared.

The colonies were first screened by selection on YPDZ (1\% yeast extract, $2 \%$ tryptone, $2 \%$ dextrose, $2 \%$ agar) plates (Zeo1000) containing Zeocin at a final concentration of $1000 \mu \mathrm{g} \mathrm{mL} \mathrm{m}^{-1}$, then on YPDZ plates containing Zeocin at final concentrations of $2000 \mu \mathrm{g} \mathrm{mL}^{-1}$ (Zeo2000) to screen for multiple copies of a cDNA gene targeted gene [35]. The $\mathrm{Mut}^{+}$phenotype of Pichia pastoris recombinants was confirmed by PCR with 5'AOX and 3'AOX primers using DNA from the Pichia pastoris transformant as the template that was extracted using a Yeast Genomic DNA Extraction kit (Tiangen, Beijing, China). Twenty colonies from the Zeo2000 plates were inoculated into $10 \mathrm{~mL}$ of YPM medium (1\% yeast extract and $2 \%$ tryptone) containing $1 \%$ methanol in a $50 \mathrm{~mL}$ flask and cultured at $28^{\circ} \mathrm{C}$ on a rotary incubator at $250 \mathrm{rpm}$ to induce the expression of the endo-1,4- $\beta$-mannanase gene. The transformant with the highest endo-1,4- $\beta$-mannanase activity in a culture supernatant following a 7 day incubation was used for further fermentation in $1 \mathrm{~L}$ flasks following the method of Bai et al. [36].

\section{Purification of recombinant endo-1,4- $\beta$-mannanase}

All purification steps were performed at $4^{\circ} \mathrm{C}$ unless stated otherwise. The crude culture supernatant was harvested by centrifugation of the culture broth at $8000 \mathrm{rpm}$ for 10 $\min$ at $4^{\circ} \mathrm{C}$. The supernatant was subjected to precipitation at $80 \%$ ammonium sulfate saturation. After dialysis against $50 \mathrm{mM}$ acetate buffer ( $\mathrm{pH} 4.0$ ), the proteins were collected and used for the next purification. The expressed $6 \times$ His-tagged proteins were purified with Ni-NTA Sepharose (Qiagen, Valencia, CA) according to the manufacturer's instructions.

\section{Enzyme activity and protein concentration assay}

The enzyme activity was determined by the DNS method according to Miller [37] with some modifications. Briefly, $100 \mu \mathrm{L}$ of enzyme diluted with $50 \mathrm{mM}$ acetate buffer (pH 4.0) was added to $900 \mu \mathrm{L}$ of $0.5 \%$ locust bean gum in $50 \mathrm{mM}$ acetate buffer $(\mathrm{pH} 4.0)$ and incubated at $80^{\circ} \mathrm{C}$ for $10 \mathrm{~min}$. The released reducing sugars were measured at $540 \mathrm{~nm}$ using D-mannose as the standard. One unit of endo-1,4- $\beta$-mannanase activity was defined as the amount of enzyme liberating $1 \mu \mathrm{mol}$ of reducing sugars per minute under the conditions described above. Protein content was determined using a BCA protein assay kit (Dingguo Changsheng Biotechnology Co., Ltd, Beijing, China), and the standard curve was generated with bovine serum albumin (BSA) as the standard.

\section{SDS-PAGE and zymography analysis}

Sodium dodecyl sulfate polyacrylamide gel electrophoresis (SDS-PAGE) was performed using a $12 \%(\mathrm{w} / \mathrm{v})$ polyacrylamide gel with a $5 \%$ stacking gel and the MiniProtean II system (BioRad) according to the method described by Laemmli [38]. The proteins were stained with Coomassie Brilliant Blue R-250 (Sigma Chemical, St. Louis, USA). The zymogram analysis was performed as previously reported by co-polymerizing $0.05 \%(\mathrm{w} / \mathrm{v})$ locust bean gum with $12 \%$ polyacrylamide gel [13]. After the separation of the enzyme samples by SDS-PAGE, the gel was soaked for $1 \mathrm{~h}$ in $2.5 \%(\mathrm{v} / \mathrm{v})$ Triton X-100 to remove the SDS and refold the proteins in the gel. The gel was then thoroughly washed three times in MilliQ water and incubated at $50^{\circ} \mathrm{C}$ for $60 \mathrm{~min}$ in $50 \mathrm{mM}$ acetate buffer ( $\mathrm{pH} 4.0)$. The gel was stained with $0.1 \%(\mathrm{w} / \mathrm{v})$ Congo red solution for $30 \mathrm{~min}$ and destained with $1 \mathrm{M} \mathrm{NaCl}$ until pale-red hydrolysis zones were observed against a red background.

\section{Effect of temperature, $\mathrm{pH}$ and various reagents on enzyme activity}

The optimal temperature for rPoMan5A activity was determined using the standard method as described above at various temperatures ranging from $30^{\circ} \mathrm{C}$ to $90^{\circ} \mathrm{C}$. To estimate thermal stability, the diluted enzyme was preincubated in $50 \mathrm{mM}$ acetate buffer ( $\mathrm{pH} \mathrm{4.0)}$ at different temperatures $\left(40-90^{\circ} \mathrm{C}\right)$ for various times in the absence of substrate and then assayed for remaining enzyme at $60^{\circ} \mathrm{C}$ using the standard DNS method.

For the estimation of optimal $\mathrm{pH}$ for rPoMan5A enzyme activity, $50 \mathrm{mM}$ different buffer solutions like glycine- $\mathrm{HCl}$ buffer ( $\mathrm{pH}$ 2.0-3.0), acetate buffer ( $\mathrm{pH}$ 4.0-6.0), sodium phosphate buffer ( $\mathrm{pH}$ 7.0-8.0), and glycine- $\mathrm{NaOH}$ buffer (pH 9.0-11.0) were used. The $\mathrm{pH}$ stability was determined at different $\mathrm{pH}$-values for $30 \mathrm{~min}$ by incubation of diluted enzyme samples in the absence of substrate at $60^{\circ} \mathrm{C}$. The residual enzyme activity was measured at $60^{\circ} \mathrm{C}$ for $10 \mathrm{~min}$ in the acetate buffer $(\mathrm{pH} 4.0)$ using the DNS method. The effect of metal ions on rPoMan5A activity was examined by incubating the enzyme with various metal ions $\left(\mathrm{BaCl}_{2}\right.$, $\mathrm{CuSO}_{4}, \mathrm{FeCl}_{3}, \mathrm{MnSO}_{4}, \mathrm{CaCl}_{2}, \mathrm{CdSO}_{4}, \mathrm{FeSO}_{4}, \mathrm{CrCl}_{3}$, $\mathrm{CoCl}_{2}, \mathrm{LiCl}, \mathrm{NiSO}_{4}, \mathrm{MgSO}_{4}$ and $\mathrm{HgCl}_{2}$ ) or reagents in 50 $\mathrm{mM}$ acetate buffer (pH 4.0) at $60^{\circ} \mathrm{C}$ for $10 \mathrm{~min}$.

\section{Substrate specificity and kinetic parameters}

The specific activity of rPoMan5A was measured using different substrates $(0.5 \%(\mathrm{w} / \mathrm{v}), \mathrm{pH} 4.0)$ in $50 \mathrm{mM}$ acetate buffer (locust bean gum, konjac mannan, guar gum, sodium carboxymethyl cellulose (CMC-Na), filter paper, and beechwood xylan). To determine the reaction rate of rPoMan5A, various mannans substrate concentrations were used to react $10 \mathrm{~min}$ at $80^{\circ} \mathrm{C}$ in acetate buffer (pH 4.0, $50 \mathrm{mM}$ ). The Michaelis-Menten constant $\left(K_{m}\right)$ and the maximum velocity $\left(V_{\max }\right)$ were calculated using Lineweaver-Burk plots. 


\section{Thin-layer chromatography (TLC) analysis of the hydrolysis products}

The analysis of hydrolysis products was performed by thin-layer chromatography using locust bean gum, konjac mannan and guar gum as substrates. The purified rPoMan5A $(5 \mu \mathrm{g})$ was incubated in a reaction volume of $1 \mathrm{~mL}$ with $0.5 \%$ of substrate at $60^{\circ} \mathrm{C}$ in $50 \mathrm{mM}$ acetate buffer ( $\mathrm{pH} 4.0$ ) for $24 \mathrm{~h}$. Aliquots were collected at different time points and boiled for $10 \mathrm{~min}$. All products were freeze-dried and dissolved in a methanol (70\%). Then, $5 \mu \mathrm{L}$ of each aliquot was spotted onto a silica plate (Merck, Germany, $10 \times 20 \mathrm{~cm}$ ), and the plates were developed twice with a solvent system consisted of chloroform-acetic acid-water (3:6:1, v/v) for 3-4 hours. Later, the plates were dried and hydrolysis products were detected by spraying with a 9:1 $(\mathrm{v} / \mathrm{v})$ mixture of methanol and sulfuric acid containing $0.2 \%$ orcinol and heating at $85^{\circ} \mathrm{C}$ for 5-10 min. Manno-oligosaccharides (mannose (M1), mannobiose (M2), mannotriose (M3), mannotetraose (M4), mannopentaose (M5), and mannohexaose (M6), Megazyme, Bray, Ireland) were used as standards.

\section{Competing interests}

The authors declare that they have no competing interests.

\section{Authors' contributions}

HPL performed the molecular genetic experiments, desired experiment and wrote the manuscript. SXL and HPZ did the enzyme production and purification, and the enzymatic activity assay. ZW and DYL directed the study and checked all the data. WR helped to revise the manuscript. YCX was the corresponding author, he and QRS supervised the work and contributed to the manuscript. All authors read the manuscript and approved to submit to this journal.

\section{Authors' information}

Jiangsu Collaborative Innovation Center for Solid Organic Waste Utilization, College of Resources and Environmental Science, Nanjing Agricultural University, Nanjing, 210095, China.

\section{Acknowledgements}

This research was financially supported by the Agricultural Ministry of China (2011-G27), Special Fund for Agro-scientific Research in the Public Interest (201203001), National key technology R\&D program (L020130249).

Received: 12 July 2014 Accepted: 9 October 2014

Published online: 28 October 2014

\section{References}

1. De O, Petkowicz C, Reicher F, Chanzy H, Taravel F, Vuong R: Linear mannan in the endosperm of Schizolobium amazonicum. Carbohydr Polym 2001, 44(2):107-112

2. Songsiriritthigul C, Buranabanyat B, Haltrich D, Yamabhai M: Efficient recombinant expression and secretion of a thermostable GH26 mannan endo-1, 4- $\beta$-mannosidase from Bacillus licheniformis in Escherichia coli. Microb Cell Fact 2010, 9(1):20.

3. Zhou $H$, Yang $Y$, Nie $X$, Yang W, Wu Y: Comparison of expression systems for the extracellular production of mannanase Man23 originated from Bacillus subtilis B23. Microb Cell Fact 2013, 12(1):78.

4. Yoshida S, Sako Y, Uchida A: Cloning, sequence analysis, and expression in Escherichia coli of a gene coding for an enzyme from Bacillus circulans K-1 that degrades guar gum. Biosci Biotechnol Biochem 1998, 62(3):514-520.

5. Bien-Cuong D, Thi-Thu D, Berrin J-G, Haltrich D, Kim-Anh T, Sigoillot J-C, Yamabhai M: Cloning, expression in Pichia pastoris, and characterization of a thermostable GH5 mannan endo-1, 4- $\beta$-mannosidase from Aspergillus niger BK01. Microb Cell Fact 2009, 8(1):59.

6. Ishizawa Cl, Jeoh T, Adney WS, Himmel ME, Johnson DK, Davis MF: Can delignification decrease cellulose digestibility in acid pretreated corn stover? Cellulose 2009, 16(4):677-686.

7. Li J-F, Zhao S-G, Tang C-D, Wang J-Q, Wu M-C: Cloning and functional expression of an acidophilic $\beta$-mannanase gene (Anman5A) from Aspergillus niger LW-1 in Pichia pastoris. J Agric Food Chem 2012, 60(3):765-773.

8. Wu M, Tang C, Li J, Zhang H, Guo J: Bimutation breeding of Aspergillus niger strain for enhancing $\beta$-mannanase production by solid-state fermentation. Carbohydr Res 2011, 346(14):2149-2155.

9. Jiang Z, Wei Y, Li D, Li L, Chai P, Kusakabe I: High-level production, purification and characterization of a thermostable $\beta$-mannanase from the newly isolated Bacillus subtilis WY34. Carbohydr Polym 2006, 66(1):88-96.

10. Dhawan S, Kaur J: Microbial mannanases: an overview of production and applications. Crit Rev Biotechnol 2007, 27(4):197-216.

11. Zhao J, Shi P, Luo H, Yang P, Zhao H, Bai Y, Huang H, Wang H, Yao B: An acidophilic and acid-stable $\beta$-mannanase from Phialophora sp. P13 with high mannan hydrolysis activity under simulated gastric conditions. $J$ Agric Food Chem 2010, 58(5):3184-3190.

12. Lu H, Luo H, Shi P, Huang H, Meng K, Yang P, Yao B: A novel thermophilic endo-beta-1,4-mannanase from Aspergillus nidulans XZ3: functional roles of carbohydrate-binding module and Thr/Ser-rich linker region. App/ Microbiol Biotechnol 2014, 98:2155-2163.

13. Liao H, Xu C, Tan S, Wei Z, Ling N, Yu G, Raza W, Zhang R, Shen Q, Xu Y: Production and characterization of acidophilic xylanolytic enzymes from Penicillium oxalicum GZ-2. Bioresour Technol 2012, 123(2):117-124.

14. Lim J, Bakar F, Yusof H, Murad A: Cloning and expression of a Trichoderma longibrachiatum $\beta$-mannanase gene in Pichia pastoris. Afr J Biotechnol 2014, 11(7):1705-1718.

15. Chen X, Cao Y, Ding Y, Lu W, Li D: Cloning, functional expression and characterization of Aspergillus sulphureus $\beta$-mannanase in Pichia pastoris. J Biotechnol 2007, 128(3):452-461.

16. Cai H, Shi P, Luo H, Bai Y, Huang H, Yang P, Yao B: Acidic $\beta$-mannanase from Penicillium pinophilum $\mathrm{C} 1$ : cloning, characterization and assessment of its potential for animal feed application. J Biosci Bioeng 2011, 112(6):551-557.

17. Cai H, Shi P, Huang H, Luo H, Bai Y, Yang P, Meng K, Yao B: An acidic $\beta$-mannanase from Penicillium sp. C6: gene cloning and over-expression in Pichia pastoris. World J Microbiol Biotechnol 2011, 27(12):2813-2819.

18. Wang Y, Shi P, Luo H, Bai Y, Huang H, Yang P, Xiong H, Yao B: Cloning, over-expression and characterization of an alkali-tolerant endo- $\beta-1$, 4-mannanase from Penicillium freii F63. J Biosci Bioeng 2012, 113(6):710-714.

19. Stålbrand H, Saloheimo A, Vehmaanperä J, Henrissat B, Penttilä M: Cloning and expression in Saccharomyces cerevisiae of a Trichoderma reesei beta-mannanase gene containing a cellulose binding domain. Appl Environ Microbiol 1995, 61(3):1090-1097.

20. Benech R-O, Li X, Patton D, Powlowski J, Storms R, Bourbonnais R, Paice M, Tsang A: Recombinant expression, characterization, and pulp prebleaching property of a Phanerochaete chrysosporium endo- $\beta$-1,4-mannanase. Enzyme Microb Technol 2007, 41(6):740-747.

21. Hägglund $P$, Eriksson T, Collén A, Nerinckx W, Claeyssens M, Stålbrand H: A cellulose-binding module of the Trichoderma reesei $\beta$-mannanase Man5A increases the mannan-hydrolysis of complex substrates. J Biotechnol 2003, 101(1):37-48.

22. Tang C-D, Li J-F, Wei X-H, Min R, Gao S-J, Wang J-Q, Yin X, Wu M-C: Fusing a carbohydrate-binding module into the Aspergillus usamii $\beta$-mannanase to improve its thermostability and cellulose-binding capacity by in silico design. PLoS One 2013, 8(5):8.

23. Luo $H$, Wang $Y$, Wang $H$, Yang J, Yang $Y$, Huang $H$, Yang $P$, Bai $Y$, Shi $P$, Fan $Y$ : A novel highly acidic $\beta$-mannanase from the acidophilic fungus Bispora sp. MEY-1: gene cloning and overexpression in Pichia pastoris. Appl Microbiol Biotechnol 2009, 82(3):453-461.

24. Gasser B, Saloheimo M, Rinas U, Dragosits M, Rodríguez-Carmona E, Baumann K, Giuliani M, Parrilli E, Branduardi P, Lang C: Protein folding and conformational stress in microbial cells producing recombinant proteins: a host comparative overview. Microb Cell Fact 2008, 7(1):11.

25. Chauhan PS, Puri N, Sharma P, Gupta N: Mannanases: microbial sources, production, properties and potential biotechnological applications. Appl Microbiol Biotechnol 2012, 93:1817-1830. 
26. Katrolia P, Yan Q, Zhang P, Zhou P, Yang S, Jiang Z: Gene cloning and enzymatic characterization of an alkali-tolerant endo-1, 4- $\beta$-mannanase from Rhizomucor miehei. J Agric Food Chem 2013, 61(2):394-401.

27. Puchart V, Vršanská M, Svoboda P, Pohl J, Ögel ZB, Biely P: Purification and characterization of two forms of endo- $\beta-1$, 4-mannanase from a thermotolerant fungus Aspergillus fumigatus IMI 385708 (formerly Thermomyces lanuginosus IMI 158749). Biochimica et Biophysica Acta 2004, 1674(3):239-250.

28. Kurakake M, Sumida T, Masuda D, Oonishi S, Komaki T: Production of galacto-manno-oligosaccharides from guar gum by $\beta$-mannanase from Penicillium oxalicum SO. J Agric Food Chem 2006, 54(20):7885-7889.

29. Lu H, Zhang H, Shi P, Luo H, Wang Y, Yang P, Yao B: A family $5 \beta$-mannanase from the thermophilic fungus Thielavia arenaria XZ7 with typical thermophilic enzyme features. Appl Microbiol Biotechnol 2013, 97:8121-8127.

30. Tamaru Y, Araki T, Amagoi H, Mori H, Morishita T: Purification and characterization of an extracellular beta-1, 4-mannanase from a marine bacterium, Vibrio sp. strain MA-138. Appl Environ Microbiol 1995, 61(12):4454-4458.

31. Van Zyl WH, Rose SH, Trollope K, Görgens JF: Fungal $\beta$-mannanases: mannan hydrolysis, heterologous production and biotechnological applications. Process Biochem 2010, 45(8):1203-1213.

32. Liao H, Sun S, Wang P, Bi W, Tan S, Wei Z, Mei X, Liu D, Raza W, Shen Q, $X \mathrm{U}$ Y: A new acidophilic endo-beta-1,4-xylanase from Penicillium oxalicum: cloning, purification, and insights into the influence of metal ions on xylanase activity. J Ind Microbiol Biotechnol 2014, 41:1071-1083.

33. Möller E, Bahnweg G, Sandermann H, Geiger H: A simple and efficient protocol for isolation of high molecular weight DNA from filamentous fungi, fruit bodies, and infected plant tissues. Nucleic Acids Res 1992, 20(22):6115-6116.

34. Wang S, He J, Cui Z, Li S: Self-formed adaptor PCR: a simple and efficient method for chromosome walking. Appl Environ Microbiol 2007, 73(15):5048-5051.

35. Cheng Y-F, Yang C-H, Liu W-H: Cloning and expression of Thermobifida xylanase gene in the methylotrophic yeast Pichia pastoris. Enzyme Microb Technol 2005, 37(5):541-546.

36. Bai Y, Wang J, Zhang Z, Shi P, Luo H, Huang H, Luo C, Yao B: Research expression of an extremely acidic $\beta$-1, 4-glucanase from thermoacidophilic Alicyclobacillus sp. A4 in Pichia pastoris is improved by truncating the gene sequence. Microb Cell Fact 2010, 33(1):9.

37. Miller GL: Use of dinitrosalicylic acid reagent for determination of reducing sugar. Anal Chem 1959, 31(3):426-428.

38. Laemmli UK: Cleavage of structural proteins during the assembly of the head of bacteriophage T4. Nature 1970, 227(5259):680-685.

doi:10.1186/s12896-014-0090-z

Cite this article as: Liao et al:: A new acidophilic thermostable endo-1,4- $\beta$ mannanase from Penicillium oxalicum GZ-2: cloning, characterization and functional expression in Pichia pastoris. BMC Biotechnology 2014 14:90.

\section{Submit your next manuscript to BioMed Central and take full advantage of:}

- Convenient online submission

- Thorough peer review

- No space constraints or color figure charges

- Immediate publication on acceptance

- Inclusion in PubMed, CAS, Scopus and Google Scholar

- Research which is freely available for redistribution 